\title{
The accelerated infectious disease risk in the Anthropocene: more outbreaks and wider global spread
}

Serge Morand $d^{1,2,3}$ and Bruno A. Walther ${ }^{* *}$

${ }^{1}$ CIRAD, UMR ASTRE, F-34398, Montpellier, France. ${ }^{2}$ CNRS - Institut des Sciences de l'Evolution de Montpellier, Université de Montpellier, France. ${ }^{3}$ Faculty of Veterinary Technology, Kasetsart University, Bangkok, Thailand ${ }^{4}$ Department of Biological Sciences, National Sun Yat-sen University, Gushan District, Kaohsiung City, 804, Taiwan. *e-mail: bawalther2009@gmail.com 
The greatly accelerated economic growth during the Anthropocene has resulted in astonishing improvements in many aspects of human well-being, but has also caused the acceleration of risks, such as the interlinked biodiversity and climate crisis. Here, we report on another risk: the accelerated infectious disease risk associated with the number and geographic spread of human infectious disease outbreaks. Using the most complete, reliable, and up-to-date database on human infectious disease outbreaks (GIDEON), we show that the number of disease outbreaks, the number of diseases involved in these outbreaks, and the number of countries affected have increased during the entire Anthropocene. Furthermore, the spatial distribution of these outbreaks is becoming more globalized in the sense that the overall modularity of the disease networks across the globe has decreased, meaning disease outbreaks have become increasingly pandemic in their nature. This decrease in modularity is correlated with the increase in air traffic. We finally show that those countries and regions which are most central within these disease networks tend to be countries with higher GDPs. Therefore, one cost of increased global mobility and greater economic growth is the increased risk of disease outbreaks and their faster and wider spread. We briefly discuss three different scenarios which decision-makers might follow in light of our results. 


\section{Introduction}

The Anthropocene has also been nicknamed the 'Great Acceleration' because various socioeconomic and Earth-System related indicators experienced a continuous and often exponential growth after the Second World War (Steffen et al., 2015a; McNeill and Engelke, 2016; Steffen et al., 2018). While this relentless growth of the human enterprise improved human well-being around the world in many aspects (Waage et al., 2010; Barrett, 2013; Permanyer and Scholl, 2019; Zheng and Qian, 2019), negative impacts have likewise increased (IPCC, 2016; IPBES, 20220). In tandem, warnings about a climate emergency (Lenton et al., 2019; Ripple et al., 2020), a sixth mass extinction (Pereira et al., 2010; Barnosky et al., 2012; Ceballos et al., 2015), increasing ocean acidification and dead zones (Hoegh-Guldberg et al., 2007; Diaz and Rosenberg, 2008; Branch et al., 2013), and even widespread ecosystem collapse (Jackson, 2008; Barnosky et al., 2012; UNEP, 2016) and transgression of safe planetary boundaries (Steffen et al., 2015b) have grown increasingly urgent. To avoid or at least dampen the anticipated or already realized changes, scientists and many others have called out for radical changes to how human economies operate and relate to human societies and their environments (Unmüßig, 2015; Simms, 2016; Walther, 2019; Ripple et al., 2020).

We here want to draw attention to another important and noteworthy feature of the Anthropocene which greatly affects public health, human well-being, and economic performance. These findings are especially pertinent as the world reels from the health, social and economic impact of the current SARS-CoV-2 pandemic (El Zowalaty and Järhult, 2020; Ghebreyesus and Swaminathan, 2020; Lorusso et al., 2020).

The increasing connectivity of human populations due to international trade and travel (Guimerà et al., 2005; Colizza et al., 2006; Brockmann and Helbing, 2013; Gabrielli et al., 2019), the rapid growth of the transport of wild and domesticated animals worldwide (Rosen and Smith, 2010; Schneider, 2012; Rohr et al., 2019; Levitt, 2020), and other factors such as the increasing encroachment of human populations on hitherto isolated wild animal populations through loss and fragmentation of wild habitats (Patz et al., 2004; Despommier et al., 2006; Pongsiri et al., 2009; Myers et al., 2013) have led to a great acceleration of infectious disease risks, e.g., the increase in emerging infectious diseases and drug-resistant microbes since 1940 (Jones et al., 2008) and the increase in the number of disease outbreaks since 1980 (Smith et al., 2014).

To expand the previous analysis (Smith et al., 2014) to the beginning of the Anthropocene, we investigated whether the number of disease outbreaks has increased since the Second World War. In addition, we examined whether the global pattern of infectious disease outbreaks changed possibly due the increasing connectivity of human populations. In other words, have the disease outbreaks 
become more globalized in the sense that these outbreaks are increasingly shared by countries worldwide?

To investigate these questions, we used a the most complete, reliable, and up-to-date global dataset (GIDEON Informatics, 2020) which had already been used in the previous analysis (Smith et al., 2014). This dataset can be used to enumerated the recorded annual number of disease outbreaks. To investigate the changing global patterns of disease outbreaks, we used this dataset to calculate two measures which have been recently introduced into ecological and parasitological studies. These two measures, namely modularity and centrality, quantify the connectivity of bipartite networks.

Modularity is defined as the extent to which nodes (specifically, sites and species for presenceabsence matrices) in a compartment are more likely to be connected to each other than to other nodes of the network (Thébault, 2013). The calculation of a modularity measure is useful for global phenomena because it allows the overall level of compartmentalization (or fragmentation) into compartments (or clusters, modules, subgroups, or subsets) of an entire dataset to be quantified. High modularity in a global network means that subgroups of countries and disease outbreaks interact more strongly among themselves (that is, within a compartment) than with the other subgroups (that is, among compartments) (Bordes et al., 2015).

Centrality is defined as the degree of the connectedness of a node (e.g., a keystone species in ecological studies; Jordán, 2009; González et al., 2010). In the context of our study, centrality is the degree of the connectedness of a country and those countries connected to it. We estimated the countries which are the potential centres of disease outbreaks by investigating the eigenvector centrality of a given country in a network of countries which share disease outbreaks among each other. Eigenvector centrality is a generalization of degree centrality, which is the number of connections a country has to other countries in terms of sharing disease outbreaks. Eigenvector centrality considers countries to be highly central if the connected countries to them through shared outbreaks are connected to many other well-connected countries (Bonacich and Lloyd, 2001; Wells et al., 2020).

Modularity and centrality analyses have been used to investigate various ecological, parasitological and epidemiological questions (e.g., Tylianakis et al., 2007; Jordán, 2009; González et al., 2010; Anderson and Sukhdeo, 2011; Bascompte and Jordano, 2014; Poisot et al., 2014; Bordes et al., 2015; Genrich et al., 2017).

Using a widely used world dataset on infectious disease outbreaks, we here present results which demonstrate that the accelerated number of disease outbreaks and their increased global spread are two further threatening aspects of the accelerated infectious disease risk associated with the globalization process which characterizes the Anthropocene. 


\section{Methods}

Data on GDP and mobility (trade, traffic, transport, travel, and tourism). The data on gross domestic product (GDP) per capita was taken from the World Bank database. It was calculated by dividing a country's GDP by its midyear population; the numbers are in current United States of America (USA) dollars from 1961 to 2018. As measures of mobility, we searched for various numerical examples of the increase in global trade, traffic, transport, travel, and tourism during the Anthropocene. The data on the air freight and air passengers were taken from the World Bank database (World Bank, 2020a; World Bank, 2020b). The database yielded the number of air passengers and the air freight in million metric tons (MT) per km from 1970 to 2017 separately for each country. The data on container movements were provided by Container Trades Statistics and the Institute of Shipping Economics and Logistics (in litt., 2020). Other examples were found through a quick literature search using the appropriate keywords; however, the illustrative examples resulting from this literature search (presented in Table 1) were not intended to be a comprehensive literature review on this topic.

Data on infectious disease outbreaks. To collate the total number of infectious disease outbreaks over the years 1940-2018, we extracted the relevant data from the medical database called GIDEON (GIDEON Informatics, 2020) which contains information on the presence and occurrence of epidemics of human infectious diseases in each country as well as the number of surveys conducted in each country. The GIDEON data are curated as records of confirmed outbreaks, are continually updated using various sources such as WHO and Promed, and are accessible via subscription. This dataset is generally considered to be the most complete, reliable, and up-to-date in the world and has been regularly used in previous macro-scale studies of infectious disease, epidemics, and pathogen diversity (e.g., Smith et al., 2007; Dunn et al., 2010; Morand et al., 2013; Morand et al., 2014; Poisot et al., 2014; Smith et al., 2014; Morand, 2015; Morand and Walther, 2018). Each row in the GIDEON dataset specifies the disease 'species', the year and the country of the outbreak. The 'annual total outbreak number' is simply the annual total number of outbreaks regardless of the disease designation and including all countries. The 'annual total disease number' uses the same data for each year as the 'annual total outbreak number' but then counts only the different infectious diseases which had at least one outbreak in that respective year. The 'annual total country number' uses the same data for each year as the 'annual total outbreak number' but then counts only the different countries which had at least one outbreak in that respective year. Our entire 1940-2018 dataset contains 17424 outbreaks of 361 human infectious diseases in 224 nations.

Statistical analyses. In our case, we built yearly bipartite networks of presence-absence matrices 
which link countries with all the recorded epidemic outbreaks. We then transformed these bipartite networks where separate nodes from countries were connected with nodes of epidemic outbreaks into unipartite networks using the tnet package (Opsahl, 2009) in R (R Development Core Team, 2019).

The calculation of modularity of bipartite networks of shared epidemic outbreaks among countries allowed us to identify modules of countries that share common epidemic outbreaks in each respective year (see Introduction) (Blondel et al., 2008; Bordes et al., 2017). We calculated our modularity measure of unipartite network for each year using igraph (Lehoucq et al., 2019). High modularity calculated in this context means that an epidemic remains relatively constrained within a few countries while low modularity means that an epidemic has spread across relatively more countries.

The calculation of the eigenvector centrality of the unipartite network of each respective year allowed us to determine the number of connections a country has to other countries in terms of epidemic outbreak sharing. Eigenvector centrality is a measure of the degree of the connectedness of a country and those countries connected to it. High centrality calculated in this context means that a country is connected to many countries which are also well-connected (Bonacich and Lloyd, 2001; Wells et al., 2020).

A visual examination of the time trend of the annual modularity measure suggested a discontinuous trend over time. To detect such a discontinuity (or breakpoint) in the trend over time, we used the R package segmented (Muggeo, 2003; Muggeo, 2008). This package allows the identification of one or more discontinuities using the bootstrap method; in other words, the decomposition of a relationship into one of more piece-wise linear relationships and the identification of breaking point(s). The standard errors of the breakpoint estimates were computed with the procedure of Clegg et al. (2009) which is implemented in the R package segmented.

Finally, we used a smooth regression to visualize the patterns of changes over time (Harrell, 2015) (e.g., for air transport, modularity, etc.).

\section{Results}

Increase in global measures of mobility and GDP. The increase in measures of mobility during the Anthropocene has been staggering, with growth percentages of up to $5600 \%$ (Table 1). Many more impressive local and regional examples exist, see, e.g., (Wilson, 1995; Wilson, 1997). For further analyses below, we only used the World Bank data on flight passengers and air freight; therefore, we detail them here. Since the 1970s, the total global number of flight passengers (Fig. 1A) and air freight have increased exponentially (Fig. 1B). The total number of flight passengers increased from around 330 million in 1970 to more than 4 billion in 2017, representing a $>1200 \%$ 
increase. The total amount of air freight increased from around 15660 million MT/km in 1970 to 220707 million MT/km in 2017, representing a $>1300 \%$ increase. Global GDP per capita (in current USA dollars) also increased exponentially from 805 dollars in 1970 to 10777 dollars in 2017, representing a $>1200 \%$ increase (Fig. 1C).

Increase in the number of outbreaks. Since the 1940s, the annual total outbreak number (Fig. 1D), the annual total disease number (Fig. 1E), and the annual total country number (Fig. 1F) have increased exponentially. However, for the annual total disease number, this increase has slowed since the 1990s. While there is some annual up-and-down variation, the overall trends are well demonstrated by the smooth line regressions. Furthermore, around 2010, the trends for the three variables began a decrease or stagnation in the actual data, but not in the smooth line regressions. A global map of the total outbreak numbers summarized from 1940 to 2018 shows a highly uneven, positively skewed distribution of outbreaks among countries (Fig. 2). The countries with the most outbreaks are the USA (1894), the United Kingdom (UK) (927), India (653), Canada (565), Japan (547), Australia (467), China (432), Spain (416), France (401), Italy (372), and Germany (371).

Decrease in the modularity of network of countries versus outbreaks. Since the 1940s, the annual modularity measure has overall decreased (Fig. 3). However, it remained at about the same level (or even increased slightly) until 1962; after 1962, there is a clear downward and almost linear trend. This discontinuity analysis of the trend (using the R package segmented) split the trend in two parts around an estimated break-point in 1962 (with a standard error of 4.10 years) with (1) a flat linear trend from 1940 to 1962 and (2) a significantly negative linear trend from 1962 to 2018.

Relationship between air travel and modularity. Since the 1970s, the annual modularity measure was negatively correlated with the annual total number of passengers (Fig. 4B) (Spearman rank test, rho $\left.^{2}=0.78, \mathrm{~F} 1,46=154.9, \mathrm{P}<0.00001\right)$ and the annual total amount of air freight (Fig. 4A) (Spearman rank test, rho $^{2}=0.84, \mathrm{~F} 1,44=230.2, \mathrm{P}<0.00001$ ).

Change in the centrality of outbreaks. We calculated the centrality values for each nation and for each year, and then calculated the mean and standard deviation using all the annual values for each country (Fig. 5). The distribution of mean values is positively skewed, with a few nations exhibiting very high centrality values (Fig. 5A). The countries with the highest centrality values are USA (0.87), India (0.51), Japan (0.48), Canada (0.46), Germany (0.41), Italy (0.38), Australia (0.38), China (0.37) and France (0.37). The average centrality measure correlated positively with the GDP 
per capita of the year 2017 with individual countries as data points (Spearman rank test, rho $^{2}=0.82$, $\mathrm{F} 1,154=14.75, \mathrm{P}=0.00018)$. The distribution of standard deviation values of centrality is approximately normally distributed, but with countries with high standard deviations concentrated in Asia, Europe, and the Americas (Fig. 5B).

We also plotted all the annual centrality values for each nation within six regions. Despite a large amount of variation over the investigated time period, the three North American countries had the highest mean of centrality values, followed by the three Pacific countries and then the European, South American, Asian and African countries (Fig. 6). These differences in centrality between the six regions are statistically significant (Kruskal-Wallis $\chi^{2}=271.58, \mathrm{df}=5, \mathrm{P}=2.2 \mathrm{e}-16$ ). Furthermore, despite the small sample size, the average centrality measure correlated positively with the GDP per capita of the year 2017 with individual regions as data points (Spearman rank test, rho $\left.^{2}=1.00, \mathrm{P}<0.00001\right)$. North American, Pacific, and European countries were more central in our unipartite disease outbreak networks. The most central positions (i.e. highest centrality values) in the network of all outbreaks were occupied by: the USA for North America; UK, Germany, and Russia for Europe; Brazil, Argentina, and Cuba for South America; India, Japan, and China for Asia; Democratic Republic of the Congo, Egypt and Kenya for Africa; and Australia for Pacific.

\section{Discussion}

\section{Short summary of results}

Our results further support the hypothesis that the Anthropocene is associated with to a great acceleration of infectious disease risks. First, we showed that the number of disease outbreaks, the number of diseases involved in these outbreaks, and the number of countries affected have increased during the entire Anthropocene (thus expanding on the results of previous studies which were more limited in time or space, e.g., Morand et al., 2013; Morand et al., 2014; Smith et al., 2014; Morand, 2015). Furthermore, these increases have mostly been exponential, although with some recent slowdowns (see Discussion below).

Second, we demonstrated that the spatial distribution of these outbreaks has become more globalized in the sense that the overall modularity of the disease networks across the globe has decreased since around 1962. In other words, clusters of disease outbreaks began to increasingly become connected with other clusters so that the fragmented nature of outbreak clusters diminished over time. Before 1962, a disease outbreak usually remained confined to one or a few closely connected countries; thereafter, disease outbreaks have become increasingly pandemic in their nature. We thus revealed a long-term, worldwide change in the biogeographic structure of human infectious diseases associated with outbreaks.

We further found that this decrease in modularity is correlated with the increase in air traffic. The 
increase in global mobility and especially in air traffic (Table 1) allows an outbreak to rapidly spread across several national and continental borders within a short period of time (see also results from modelling and real-world data below).

Third, we demonstrated which countries and regions are most central within these disease networks. Countries which are more centrally located within these disease networks tend to be also the more developed and emerging countries with significantly higher GDPs. Therefore, one cost of increased global mobility (which is currently tightly linked to economic growth and globalization, see Discussion below) is the increased risk of disease outbreaks and their faster and wider spread (although we note that the risk per capita may be decreasing, Smith et al., 2014).

\section{Limitations of this study}

Before we discuss the implications of our results, we address possible limitations and biases. While GIDEON is generally acknowledged to be the most complete, reliable, and up-to-date global dataset on infectious disease outbreaks, we nevertheless should consider that (1) there may have been some underreporting in the early part of the Anthropocene, and (2) recent outbreaks may not have been entered into GIDEON yet.

(1) There may have been some underreporting of infectious disease outbreaks during the early parts of the Anthropocene in developing countries. However, the imposition in the 1980s of the socalled Washington Consensus imposed by the International Monetary Fund, World Bank and United States Department of the Treasury and the resulting the structural adjustment programs dramatically decreased the public health and education capabilities of developing countries (e.g., Oliver, 2006; Abul Hossen and Westhues, 2012; Kebede et al., 2019) which should also have affected reporting rates. However, we see no evidence of a slowdown of our trends (Figures 1D-F) in the 1980s and 1990s.

While we cannot exclude the possibility of some underreporting of disease outbreaks during the early part of the Anthropocene, it is rather unlikely that the large increases of several hundreds of percent which we documented in Figures 1D-F are entirely due to underreporting. Since the overall trends are so consistent and so large over a relatively long period of time, we argue that these trends are real even if the actual numbers may be off by a few percentage points.

(2) The recent slowdowns shown in Figures 1D-F could be real or due to the most recent outbreaks not having been entered into GIDEON yet. If they are real, they are not really influencing the overall decade-long trends documented here. However, if they are due to underreporting, then the documented trends would be even stronger.

Although it is generally acknowledged that correlation does not prove causation, the correlation between air travel and modularity specifically (Fig. 4), and the relationship between increased 
mobility and the faster and wider spread of disease outbreaks (Table 1, Figures 1 and 3) in general make sense given theoretical models and real-world evidence (see Discussion below). However, we acknowledge that other factors may be responsible, especially variables which may covary with mobility measures. Further causal analyses are therefore required, but these are beyond the scope of this study.

\section{General discussion and future implications}

The starting point of a disease outbreak is due to a variety of local conditions or factors (Morand and Lajaunie, 2017; Morand and Figuié, 2018). For instance, Jones et al. (2008) related the emergence of infectious diseases to human population density and growth, latitude, and wildlife host richness, and Plowright et al. (2008) specified ecological drivers for several emerging infectious diseases. There may be several reasons why the number of outbreaks is increasing, which are reasons due to local conditions at the source of the outbreak (e.g., probably the presence of a seafood market for the current SARS-CoV-2 pandemic, Zhou et al., 2020). Such factors may be the increasing number of drug-resistant microbes, higher contact rates with wildlife, increased livestock and global food production, urbanization, deforestation, agricultural intensification, and others (Wilcox and Gubler, 2005; Jones et al., 2008; Plowright et al., 2008; Keesing et al., 2010; Smith and Guégan, 2010; Morand et al., 2014; Johnson et al., 2015; Hassell et al., 2017; Jorgensen et al., 2018; McMahon et al., 2018; Rohr et al., 2019).

However, after emergence, the local, regional, or global spread of a disease is of course dependent on many other factors of which host mobility is usually one of the most important ones. This is of course especially true for directly transmitted human pathogens (Walther and Ewald, 2004, and studies cited below), although mobility of humans as well as vectors are also important for the global spread of vector-borne diseases (Tatem et al., 2006; Brown et al., 2012; Eritja et al., 2017; Golnar et al., 2018; Oliveira et al., 2018).

Theoretical models predict that increased mobility leads to a faster and more wide-ranging spread of a disease outbreak, and, vice versa, decreased mobility slows and contains the spread of an outbreak. Modelling the spread of the SARS-CoV-1 pandemic, Hufnagel et al. (2004) demonstrated that two control strategies, shutting down airport connections and isolating cities, reduced the spread of the virus. Drastic travel limitations also delayed a pandemic by a few weeks in a model of the global spread of influenza (Colizza et al., 2007). Similarly, increasing levels of (1) isolation of infectious hosts, household quarantine and related behavioral changes which reduce transmission rates and (2) air traffic reduction increasingly slowed the global spread of influenza, although the latter control strategy required the almost complete halt of global air traffic (Cooper et al., 2006; Ferguson et al., 2006; Flahault et al., 2006; Hollingsworth et al., 2006; Epstein et al., 2007; Bajardi 
et al., 2011). Epstein et al. (2007) emphasized that a combination of both control strategies would be even more effective, a result mirrored by Mao (2011) for a model at the city scale. Crucially, Hollingsworth et al. (2006) also showed a significant decrease in the number of countries affected if travel reductions are combined with other control strategies to reduce transmission rates. This result was confirmed by Cooper et al. (2006) and Flahault et al. (2006) who found that fewer cities (distributed around the world) were affected by major outbreaks if sufficiently early and significant travel and transmission reductions were implemented. In a simulated smallpox attack, even gradual and mild behavioral changes had a dramatic impact in slowing the epidemic (Del Valle et al., 2005). Another model suggested that public health policies that encourage self-quarantine by infected people can lower disease prevalence (Chen et al., 2011).

Real-world examples also demonstrate the link between increased mobility and faster disease outbreaks. Real data on influenza in the USA showed that a reduction in air travel resulted in a delayed and prolonged influenza season (Brownstein et al., 2006a; Brownstein et al., 2006b). Similarly, the presence of airports and railway stations significantly advanced the arrival of influenza during the 2009 pandemic in China (Cai et al., 2019). Global connectivity due to air traffic allows an outbreak to rapidly spread across several national and continental borders within a short period of time. For example, the Ebola virus outbreak was brought into the continental USA onboard a commercial flight from Liberia because the host was asymptomatic during the flight (CDC, 2014). Sevilla (2018) reviewed and modelled how air travel can aid the global spread of Ebola, H1N1 influenza, SARS-CoV-1, and pneumonic plague. A systematic review of the effectiveness of travel reductions concluded that internal travel restrictions as well as international border restrictions both delay the spread of influenza epidemics (Mateus et al., 2014).

Therefore, given the staggering global increase in global mobility during the Anthropocene documented in Table 1, the increase of the number of disease outbreaks, of diseases involved in these outbreaks, and of countries affected, as well as the decrease of modularity of these disease outbreaks make sense because the mobility of humans, other living beings, and goods (which can act as carriers or vectors) all facilitate the spread of disease and species (e.g., Smith and Guégan, 2010; Findlater and Bogoch, 2018; Sardain et al., 2019).

Given the lack of any antiviral or vaccine treatment, the current SARS-CoV-2 pandemic has forced governments to drastically curtail people's mobility and introduce continent-wide social distancing and lockdowns in order to at least slow its spread by lowering transmission rates. Thus, the governments' responses to this acute global health emergency actually mirror many of the recommendations which were given by the various modelling studies cited above. It should also be noted that the restriction of people's mobility (and its most extreme form, quarantine) and social distancing were already used before the advent of the germ theory of disease and are even used to 
some extent by other species (Hart, 2011; Tognotti, 2013; Bashford, 2016).

Given the link between mobility and disease outbreaks documented by our study, the key question which decision-makers and society at large should ask are which of the following three scenarios (which we outline in very broad terms only) should we aim for in the coming decades.

(1) Once the current SARS-CoV-2 pandemic is over, we continue on our path of ever increasing mobility without regard to the costs in terms of the accelerated infectious disease risk.

(2) We attempt to slow down or even reverse mobility rates of infected hosts and vectors.

(3) We attempt to slow down or even reverse mobility rates of humans and other carriers and vectors (in other words, decrease many or all of the mobility measures in Table 1). We briefly discuss the implications of each scenario. However, this discussion is by no means exhaustive, but meant to stimulate further discussion and study which are urgently needed to come to terms with the accelerated infectious disease risk of the Anthropocene.

(1) Most likely, at least in the short-term, economic and political decision-makers will return to 'business-as-usual' which means increasing mobility rates even further. After all, various projections predict more immense increases of mobility within the next few decades. For example, international tourist arrivals worldwide are expected to increase by $3.3 \%$ a year between 2010 and 2030 to reach 1.8 billion by 2030 (UNWTO, 2020) from the 1.4 billion recorded in 2018 (Table 1). WATF (2019) predicted a 3.7\%, 2.3\%, and 2.0\% annual increase in passenger traffic, air cargo, and aircraft movements, respectively, until 2040. Sardain et al. (2019) predicted a 240-1209\% increase in global maritime traffic by 2050 while the ITF (2019) projected an average $3.4 \%$ annual growth in the demand for global freight until 2050. Over the next 20 years, air passenger traffic and the number of flying air freighters are predicted to increase by $100 \%$ and $30 \%$, respectively (IATA, 2017). Purwanto et al. (2017) predicted that, from 2005 to 2050, world passenger transport will increase from 34.2 to 73.0 trillion passenger-km, world freight demand from 26.3 to 50.8 billion MT-km, the world fleet of passenger cars from 735 to 1400 million vehicles, the world fleet of road freight vehicles from 107 to 160 million vehicles, the world fleet of rail vehicles from 297000 to 622000 vehicles, the world fleet of aircraft from 13410 to 21335 , and the maritime fleet from 901 to 2027 million dwt.

In addition to the environmental and social costs and risks of this scenario (e.g., increasing landuse change, greenhouse gas emissions, resource use and waste production, etc.), including the risk of widespread ecosystem collapse (see Introduction), we can now add the cost of an increasing infectious disease risk. While our study only focused on human infectious diseases, this cost related to increased mobility is also increasing for animal and plant disease outbreaks as well as alien species introductions (e.g., Anderson et al., 2004; Fisher et al., 2012; Bélanger and Pilling, 2019; Sardain et al., 2019). While outbreaks of animal and plant diseases may be amenable to a cost- 
benefit analysis (Tildesley et al., 2019), the current SARS-CoV-2 pandemic has clearly shown that simple cost-benefit analyses cannot be applied when the lives of millions of people are at stake (note that another emerging infectious disease, the global HIV pandemic, has claimed 32 million lives so far). Given that another pandemic becomes more likely with increasing rates of emergence and increasing global mobility, a 'business-as-usual' scenario is automatically associated with further epidemics and pandemics, possibly killing further millions of humans and devastating local and regional economies or even the global economy.

If a 'business-as-usual' scenario is followed with regards to global mobility, countries and the world community should at least invest in better detection and surveillance methods to catch and contain the next pandemic as early as possible, and in better preparedness of public health facilities in case the next pandemic nevertheless gets out of hand (Jain et al., 2018; Bedford et al., 2019; Di Marco et al., 2020). However, this scenario nevertheless will likely be associated with an increased number of epidemic outbreaks (some of which may become devastating pandemics), given the results of our study.

(2) Consequently, the most realistic and agreeable scenario may be to slow down or even reverse the mobility rates of infected hosts and vectors. Again, the current SARS-CoV-2 pandemic has demonstrated that identifying infected hosts and reducing secondary infection rates caused by these infected hosts appear to be the most successful strategies to achieve elimination of the outbreak (e.g., Baker and Wilson, 2020; Baker et al., 2020). The required measures, such as mass home quarantine, restrictions on travel, expanded testing and contact tracing, and additional surveillance measures, are thus mostly focused on (1) identifying and isolating infected hosts (which means to drastically restrict their mobility) and (2) drastic restrictions of mobility for uninfected hosts.

While the latter is possible in crisis situations, it cannot be a long-term solution to the quandary of the increased infectious disease risk of the Anthropocene unless we want to decrease our total global mobility (see scenario 3 below). Therefore, much improved identification and isolation infected hosts may be the way forward. Already, such measures have been adopted during the current SARS-CoV-2 pandemic, e.g., body temperature checks for every air travel passenger even though they appear to be ineffective (Cohen and Bonifield, 2020). However, if efficient and reliable health checks which can identify various diseases and which can be administered relatively timeand cost-efficiently to large numbers of passengers could be implemented, we may be able to significantly restrict the mobility of infected hosts. While such a proposal may sound like "pie in the sky" at the moment, rapid advances in diagnostic techniques, such as translational proteomics, may soon allow us to identify infected hosts using simple breathalyzer, saliva, or urine tests (Athlin et al., 2017; Nakhleh et al., 2017; Tao et al., 2019; Zainabadi et al., 2019). Furthermore, hygienic measures, such as the enforcement of handwashing and the wearing of facemasks in public 
transport hubs, complete and regular disinfection of important traffic hubs and vehicles (including the air and all surfaces), and much better vector control should become mandatory global standards of public health (e.g., Grout and Speakman, 2019; Nicolaides et al., 2019, reviewed in Huizer et al., 2015), especially in the most central of traffic hubs, such as the world's most connected airports (Guimerà et al., 2005; Bajardi et al., 2011). Such measures would certainly help to decrease the mobility of infected hosts and thus the transmission and global spread of diseases.

(3) The most sustainable scenario is, however, to decrease or even reverse global mobility rates of humans and other carriers and vectors, especially if it is part and parcel of a much larger movement towards global sustainability by reducing humanity's environmental footprint and replacing unsustainable economic growth with sustainable economic degrowth (Schneider et al., 2010; Daly and Farley, 2011; Alexander, 2012; Czech, 2013; Galaz, 2014; Cosme et al., 2017; Weiss and Cattaneo, 2017; Chiengkul, 2018; Sandberg et al., 2019; Schmid, 2019). Such a general, comprehensive and global slowdown of mobility of both uninfected and infected people and vectors would be opposed for many reasons and by many interest groups, mainly based on economic arguments based around the need for continuous economic growth which has so far almost always been positively linked with increased mobility (e.g., Arvin et al., 2015; Hakim and Merkert, 2016; UNWTO, 2017; Saidi et al., 2018; Nasreen et al., 2020). It is to some extent possible to decouple mobility from economic growth (Loo and Banister, 2016; Lane, 2019), but even if such a decoupling was achieved, it would not sufficiently reduce mobility to significantly decrease infectious disease risks. As the modelling results cited above and the experience with the current SARS-CoV-2 pandemic clearly show, only a huge reduction in mobility and contact rates is sufficient to achieve a slowdown or halt of a highly contagious disease outbreak which is already under way.

Yet, a decrease in global levels of mobility should also decrease the overall number of disease outbreaks, according to our results (which is different to just slowing and containing the spread of an outbreak, see Discussion above). Therefore, the many environmental benefits of economic degrowth and deglobalization would be augmented by a global health benefit, the almost certain decrease of infectious disease outbreaks. Since economic degrowth and deglobalization have been advocated by many sustainability experts to deal with the currently converging environmental crises (climate change, ocean acidification, biodiversity, etc., see references above), our results further strengthen the argument for such a 'not-business-as-usual' scenario.

Moreover, the economic degrowth scenario would also ameliorate many of the local conditions or factors associated with the emergence of outbreaks (such as increased livestock production and contact rates with wildlife, climate change, loss and fragmentation of natural habitats caused by urbanization and agricultural intensification, etc.) thus further decreasing the likelihood of disease 
outbreaks.

In addition, we have a growing understanding that the presence of abundant biodiversity and healthy ecosystems has an overall positive effect on human well-being and health (Chivian and Bernstein, 2008; Wood et al., 2014; Sandifer et al., 2015; Walther et al., 2016; Morand and Lajaunie, 2017; McMahon et al., 2018) which should count as an additional health benefit of the economic degrowth scenario.

\section{Conclusions}

Naturally, decreasing mobility is a moral and political choice which can be informed by science, but not answered by science. However, given all the current negative impacts of high mobility (greenhouse gas emissions, land-use and land-cover change and the resulting habitat loss and fragmentation due to transportation infrastructure and energy production, transport of alien species, etc.), maybe it is time to ask whether it is morally justified, for example, to move the equivalent of all the inhabitants of a small town across a continent so that a football team can be supported by its fans during an away game? Is it necessary to fly halfway around the world for a weekend shopping trip? Is it really most cost-efficient for supply chains to cover the entire globe when all the externalities are included? Is long-term sustainability achievable with ever higher rates of mobility? The demand for ever-increasing mobility is putting many stresses on the Earth system and therefore also on many aspects of human well-being and health. In this study, we documented another one: The public health risks of an increasing number of disease outbreaks and their increasingly global spread. Even without the devastating current impacts of the SARS-CoV-2 pandemic, the additional disease outbreak burden associated with our highly mobile and migratory human societies is a definite cost which must be considered in its moral and ethical implications as we consider the future trajectory of the Anthropocene (Ehrlich and Ehrlich, 2013; Steffen et al., 2018; Schill et al., 2019). 
bioRxiv preprint doi: https://doi.org/10.1101/2020.04 20 049866; this version posted April 20, 2020. The copyright holder for this preprint (which was not certified by peer review) is the author/funder, who has granted bioRxiv a license to display the preprint in perpetuity. It is made available under aCC-BY-NC-ND 4.0 International license.

\section{Acknowledgements}

This work was part of theFutureHealthSEA project funded by the French ANR (ANR-17-CE350003-01). S.M. is supported by the Thailand International Cooperation Agency (TICA) "Animal Innovative Health". We sincerely thank Dieter Stockmann from the Institute of Shipping Economics and Logistics (ISL) and Claire Thackeray from Container Trades Statistics (CTS) for providing data about container movements, Jean Tournadre for providing data about ship numbers, and Ting-Wu Chuang for providing references. 


\section{References}

Abul Hossen, M., Westhues, A., 2012. The medicine that might kill the patient: structural adjustment and its impacts on health care in Bangladesh. Soc. Work Public Health 27, 213-228.

Alexander, S., 2012. Planned economic contraction: the emerging case for degrowth. Environ. Polit. 21, 349-368.

Anderson, P.K., Cunningham, A.A., Patel, N.G., Morales, F.J., Epstein, P.R., Daszak, P., 2004. Emerging infectious diseases of plants: pathogen pollution, climate change and agrotechnology drivers. Trends Ecol. Evol. 19, 535-544.

Anderson, T.K., Sukhdeo, M.V.K., 2011. Host centrality in food web networks determines parasite diversity. PLoS ONE 6, 9.

Arvin, M.B., Pradhan, R.P., Norman, N.R., 2015. Transportation intensity, urbanization, economic growth, and $\mathrm{CO} 2$ emissions in the G-20 countries. Util. Policy 35, 50-66.

Athlin, S., Iversen, A., Ozenci, V., 2017. Comparison of the ImmuView and the BinaxNOW antigen tests in detection of Streptococcus pneumoniae and Legionella pneumophila in urine. Eur. J. Clin. Microbiol. Infect. Dis. 36, 1933-1938.

Bajardi, P., Poletto, C., Ramasco, J.J., Tizzoni, M., Colizza, V., Vespignani, A., 2011. Human mobility networks, travel restrictions, and the global spread of $2009 \mathrm{H} 1 \mathrm{~N} 1$ pandemic. PLoS ONE 6, e16591.

Baker, M., Wilson, N., 2020. Elimination: what New Zealand's coronavirus response can teach the world. The Guardian. https://www.theguardian.com/world/2020/apr/10/elimination-what-newzealands-coronavirus-response-can-teach-the-world (10 April).

Baker, M.G., Kvalsvig, A., Verrall, A.J., Telfar-Barnard, L., Wilson, N., 2020. New Zealand's elimination strategy for the COVID-19 pandemic and what is required to make it work. N. Z. Med. J. 133, 10-14.

Barnosky, A.D., Hadly, E.A., Bascompte, J., Berlow, E.L., Brown, J.H., Fortelius, M., Getz, W.M., Harte, J., Hastings, A., Marquet, P.A., 2012. Approaching a state shift in Earth's biosphere. Nature 486, 52-58.

Barrett, C.B., (Ed.), 2013. Food security and sociopolitical stability. Oxford University Press, Oxford, UK.

Bascompte, J., Jordano, P., 2014. Mutualistic networks. Princeton University Press, Princeton, New Jersey, USA.

Bashford, A., 2016. Quarantine: Local and global histories. Palgrave Macmillan, Basingstoke, UK. Bedford, J., Farrar, J., Ihekweazu, C., Kang, G., Koopmans, M., Nkengasong, J., 2019. A new twenty-first century science for effective epidemic response. Nature 575, 130-136. 
Bélanger, J., Pilling, D., 2019. The state of the world's biodiversity for food and agriculture. FAO Commission on Genetic Resources for Food and Agriculture Assessments, Rome, Italy. http://www.fao.org/3/CA3129EN/ca3129en.pdf

Blondel, V.D., Guillaume, J.-L., Lambiotte, R., Lefebvre, E., 2008. Fast unfolding of community hierarchies in large network. Journal of Statistical Mechanics-Theory and Experiment 10, P10008.

Bonacich, P., Lloyd, P., 2001. Eigenvector-like measures of centrality for asymmetric relations. Soc. Networks 23, 191-201.

Bordes, F., Caron, A., Blasdell, K., de Garine-Wichatitsky, M., Morand, S., 2017. Forecasting potential emergence of zoonotic diseases in South-East Asia: network analysis identifies key rodent hosts. J. Appl. Ecol. 54, 691-700.

Bordes, F., Morand, S., Pilosof, S., Claude, J., Krasnov, B.R., Cosson, J.-F., Chaval, Y., Ribas, A., Chaisiri, K., Blasdell, K., Herbreteau, V., Dupuy, S., Tran, A., 2015. Habitat fragmentation alters the properties of a host-parasite network: rodents and their helminths in South-East Asia. J. Anim. Ecol. 84, 1253-1263.

Branch, T.A., DeJoseph, B.M., Ray, L.J., Wagner, C.A., 2013. Impacts of ocean acidification on marine seafood. Trends Ecol. Evol. 28, 178-186.

Brockmann, D., Helbing, D., 2013. The hidden geometry of complex, network-driven contagion phenomena. Science 342, 1337-1342.

Brown, E.B.E., Adkin, A., Fooks, A.R., Stephenson, B., Medlock, J.M., Snary, E.L., 2012. Assessing the risks of West Nile virus-infected mosquitoes from transatlantic aircraft: Implications for disease emergence in the United Kingdom. Vector-Borne Zoonotic Dis. 12, 310320.

Brownstein, J.S., Wolfe, C.J., Mandl, K.D., 2006a. Air travel and the spread of influenza: Authors' reply. PLoS Med. 3, e502.

Brownstein, J.S., Wolfe, C.J., Mandl, K.D., 2006b. Empirical evidence for the effect of airline travel on inter-regional influenza spread in the United States. PLoS Med. 3, 1826-1835.

Cai, J., Xu, B., Chan, K.K.Y., Zhang, X., Zhang, B., Chen, Z.Y., Xu, B., 2019. Roles of different transport modes in the spatial spread of the 2009 influenza a(h1n1) pandemic in mainland China. Int. J. Environ. Res. Public Health 16, 15.

CDC, 2014. CDC and Texas health department confirm first ebola case diagnosed in the U.S. CDC Newsroom. https://www.cdc.gov/media/releases/2014/s930-ebola-confirmed-case.html (30 September). 
Ceballos, G., Ehrlich, P.R., Barnosky, A.D., García, A., Pringle, R.M., Palmer, T.M., 2015.

Accelerated modern human-induced species losses: Entering the sixth mass extinction. Sci. Adv. $1, \mathrm{e} 1400253$.

Chen, F., Jiang, M., Rabidoux, S., Robinson, S., 2011. Public avoidance and epidemics: Insights from an economic model. J. Theor. Biol. 278, 107-119.

Chiengkul, P., 2018. The degrowth movement: Alternative economic practices and relevance to developing countries. Alternatives 43, 81-95.

Chivian, E., Bernstein, A., (Eds.), 2008. Sustaining life: How human health depends on biodiversity. Oxford University Press, Oxford, UK.

Clegg, L.X., Hankey, B.F., Tiwari, R., Feuer, E.J., Edwards, B.K., 2009. Estimating average annual per cent change in trend analysis. Stat. Med. 28, 3670-3682.

Cohen, E., Bonifield, J., 2020. No US coronavirus cases were caught by airport temperature checks. Here's what has worked. CNN. https://edition.cnn.com/2020/02/19/health/coronavirus-airporttemperature-checks/index.html (20 February).

Colizza, V., Barrat, A., Barthelemy, M., Valleron, A.-J., Vespignani, A., 2007. Modeling the worldwide spread of pandemic influenza: Baseline case and containment intervention. PLoS Med. 4, e13.

Colizza, V., Barrat, A., Barthélemy, M., Vespignani, A., 2006. The role of the airline transportation network in the prediction and predictability of global epidemics. Proc. Natl. Acad. Sci. USA 103, 2015-2020.

Cooper, B.S., Pitman, R.J., Edmunds, W.J., Gay, N.J., 2006. Delaying the international spread of pandemic influenza. PLoS Med. 3, e212.

Cosme, I., Santos, R., O'Neill, D.W., 2017. Assessing the degrowth discourse: A review and analysis of academic degrowth policy proposals. J. Clean Prod. 149, 321-334.

Czech, B., 2013. Supply shock: economic growth at the crossroads and the steady state solution. New Society Publishers.

Daly, H.E., Farley, J., 2011. Ecological economics: principles and applications. Island Press, Washington, D.C., USA.

Del Valle, S., Hethcote, H., Hyman, J.M., Castillo-Chavez, C., 2005. Effects of behavioral changes in a smallpox attack model. Math. Biosci. 195, 228-251.

Despommier, D., Ellis, B.R., Wilcox, B.A., 2006. The role of ecotones in emerging infectious diseases. EcoHealth 3, 281-289.

Di Marco, M., Baker, M.L., Daszak, P., De Barro, P., Eskew, E.A., Godde, C.M., Harwood, T.D., Herrero, M., Hoskins, A.J., Johnson, E., Karesh, W.B., Machalaba, C., Garcia, J.N., Paini, D., 
Pirzl, R., Smith, M.S., Zambrana-Torrelio, C., Ferrier, S., 2020. Sustainable development must account for pandemic risk. Proc. Natl. Acad. Sci. USA 117, 3888-3892.

Diaz, R.J., Rosenberg, R., 2008. Spreading dead zones and consequences for marine ecosystems. Science 321, 926-929.

Dunn, R.R., Davies, T.J., Harris, N.C., Gavin, M.C., 2010. Global drivers of human pathogen richness and prevalence. Proc. R. Soc. Lond. B 277, 2587-2595.

Ehrlich, P.R., Ehrlich, A.H., 2013. Can a collapse of global civilization be avoided? Proc. R. Soc. Lond. B 280, 20122845.

El Zowalaty, M.E., Järhult, J.D., 2020. From SARS to COVID-19: A previously unknown SARSCoV-2 virus of pandemic potential infecting humans-Call for a One Health approach. One Health 100124.

Epstein, J.M., Goedecke, D.M., Yu, F., Morris, R.J., Wagener, D.K., Bobashev, G.V., 2007. Controlling pandemic flu: The value of international air travel restrictions. PLoS One 2, 11. Eritja, R., Palmer, J.R., Roiz, D., Sanpera-Calbet, I., Bartumeus, F., 2017. Direct evidence of adult Aedes albopictus dispersal by car. Sci. Rep. 7, 1-15.

Ferguson, N.M., Cummings, D.A.T., Fraser, C., Cajka, J.C., Cooley, P.C., Burke, D.S., 2006.

Strategies for mitigating an influenza pandemic. Nature 442, 448-452.

Findlater, A., Bogoch, II, 2018. Human mobility and the global spread of infectious diseases: a focus on air travel. Trends Parasitol. 34, 772-783.

Fisher, M.C., Henk, D.A., Briggs, C.J., Brownstein, J.S., Madoff, L.C., McCraw, S.L., Gurr, S.J., 2012. Emerging fungal threats to animal, plant and ecosystem health. Nature 484, 186-194.

Flahault, A., Vergu, E., Coudeville, L., Grais, R.F., 2006. Strategies for containing a global influenza pandemic. Vaccine 24, 6751-6755.

Gabrielli, L., Deutschmann, E., Natale, F., Recchi, E., Vespe, M., 2019. Dissecting global air traffic data to discern different types and trends of transnational human mobility. EPJ Data Sci. 8, 26.

Galaz, V., 2014. Global environmental governance, technology and politics: the Anthropocene gap. Edward Elgar, Cheltenham, UK.

Genrich, C.M., Mello, M.A.R., Silveira, F.A.O., Bronstein, J.L., Paglia, A.P., 2017. Duality of interaction outcomes in a plant-frugivore multilayer network. Oikos 126, 361-368.

Ghebreyesus, T.A., Swaminathan, S., 2020. Scientists are sprinting to outpace the novel coronavirus. Lancet. https://doi.org/10.1016/S0140-6736(20)30420-7

GIDEON Informatics, 2020. Global Infectious Disease and Epidemiology Online Network. https://www.gideononline.com/

Golnar, A.J., Kading, R.C., Hamer, G.L., 2018. Quantifying the potential pathways and locations of Rift Valley fever virus entry into the United States. Transbound. Emerg. Dis. 65, 85-95. 
González, A.M.M., Dalsgaard, B., Olesen, J.M., 2010. Centrality measures and the importance of generalist species in pollination networks. Ecol. Complex. 7, 36-43.

Grout, A., Speakman, E.M., 2019. Are we there yet? In-flight food safety and cabin crew hygiene practices. J. Environ. Health 82, 30-32.

Guimerà, R., Mossa, S., Turtschi, A., Amaral, L.A.N., 2005. The worldwide air transportation network: Anomalous centrality, community structure, and cities' global roles. Proc. Natl. Acad. Sci. USA 102, 7794-7799.

Hakim, M.M., Merkert, R., 2016. The causal relationship between air transport and economic growth: Empirical evidence from South Asia. J. Transp. Geogr. 56, 120-127.

Harrell, F.E., 2015. Regression modeling strategies: With applications to linear models, logistic and ordinal regression, and survival analysis. Second edition. Springer, New York, USA.

Hart, B.L., 2011. Behavioural defences in animals against pathogens and parasites: parallels with the pillars of medicine in humans. Phil. Trans. Roy. Soc. Lond. B 366, 3406-3417.

Hassell, J.M., Begon, M., Ward, M.J., Fevre, E.M., 2017. Urbanization and disease emergence: Dynamics at the wildlife-livestock-human interface. Trends Ecol. Evol. 32, 55-67.

Hoegh-Guldberg, O., Mumby, P.J., Hooten, A.J., Steneck, R.S., Greenfield, P., Gomez, E., Harvell, C.D., Sale, P.F., Edwards, A.J., Caldeira, K., Knowlton, N., Eakin, C.M., Iglesias-Prieto, R., Muthiga, N., Bradbury, R.H., Dubi, A., Hatziolos, M.E., 2007. Coral reefs under rapid climate change and ocean acidification. Science 318, 1737-1742.

Hollingsworth, T.D., Ferguson, N.M., Anderson, R.M., 2006. Will travel restrictions control the international spread of pandemic influenza? Nat. Med. 12, 497-499.

Hufnagel, L., Brockmann, D., Geisel, T., 2004. Forecast and control of epidemics in a globalized world. Proc. Natl. Acad. Sci. USA 101, 15124-15129.

Huizer, Y.L., Swaan, C.M., Leitmeyer, K.C., Timen, A., 2015. Usefulness and applicability of infectious disease control measures in air travel: A review. Travel Med. Infect. Dis. 13, 19-30.

IATA, 2017. IATA Annual Review 2017. International Air Transport Association (IATA), Montreal, Canada.

IPBES, 20220. Global Assessment Report on Biodiversity and Ecosystem Services. IPBES, https://ipbes.net/global-assessment

IPCC, 2016. Fifth Assessment Report (AR5). Intergovernmental Panel on Climate Change, https://www.ipcc.ch/report/ar5/

ISL, 2017. Shipping statistics and market review. Volume 61 - No. 7. Institute of Shipping Economics and Logistics, Bremen, Germany.

ITF, 2019. ITF Transport Outlook 2019. OECD Publishing, Paris, France. 
Jackson, J.B.C., 2008. Ecological extinction and evolution in the brave new ocean. Proc. Natl. Acad. Sci. USA 105, 11458-11465.

Jain, V., Duse, A., Bausch, D.G., 2018. Planning for large epidemics and pandemics: challenges from a policy perspective. Curr. Opin. Infect. Dis. 31, 316-324.

Johnson, C.K., Hitchens, P.L., Evans, T.S., Goldstein, T., Thomas, K., Clements, A., Joly, D.O., Wolfe, N.D., Daszak, P., Karesh, W.B., Mazet, J.K., 2015. Spillover and pandemic properties of zoonotic viruses with high host plasticity. Sci Rep 5, 8 .

Jones, K.E., Patel, N.G., Levy, M.A., Storeygard, A., Balk, D., Gittleman, J.L., Daszak, P., 2008. Global trends in emerging infectious diseases. Nature 451, 990-993.

Jordán, F., 2009. Keystone species and food webs. Phil. Trans. Roy. Soc. Lond. B 364, 1733-1741. Jorgensen, P.S., Aktipis, A., Brown, Z., Carriere, Y., Downes, S., Dunn, R.R., Epstein, G., Frisvold, G.B., Hawthorne, D., Grohn, Y.T., Gujar, G.T., Jasovsky, D., Klein, E.Y., Klein, F., Lhermie, G., Mota-Sanchez, D., Omoto, C., Schluter, M., Scott, H.M., Wernli, D., Carroll, S.P., Living Resistance, P., 2018. Antibiotic and pesticide susceptibility and the Anthropocene operating space. Nat. Sustain. 1, 632-641.

Kebede, E., Goujon, A., Lutz, W., 2019. Stalls in Africa's fertility decline partly result from disruptions in female education. Proc. Natl. Acad. Sci. USA 116, 2891-2896.

Keesing, F., Belden, L.K., Daszak, P., Dobson, A., Harvell, C.D., Holt, R.D., Hudson, P., Jolles, A., Jones, K.E., Mitchell, C.E., Myers, S.S., Bogich, T., Ostfeld, R.S., 2010. Impacts of biodiversity on the emergence and transmission of infectious diseases. Nature 468, 647-652.

Lane, B.W., 2019. Revisiting 'An unpopular essay on transportation:' The outcomes of old myths and the implications of new technologies for the sustainability of transport. J. Transp. Geogr. 81, 102535.

Lehoucq, R., Maschhoff, K., Sorensen, D., Yang, C., Csardi, G., 2019. Package 'igraph'. https://igraph.org/r/doc/igraph.pdf

Lenton, T.M., Rockström, J., Gaffney, O., Rahmstorf, S., Richardson, K., Steffen, W., Schellnhuber, H.J., 2019. Climate tipping points - too risky to bet against. Nature 575, 592-595.

Levitt, T., 2020. Two billion and rising: the global trade in live animals in eight charts. The Guardian. https://www.theguardian.com/environment/2020/jan/20/two-billion-and-rising-theglobal-trade-in-live-animals-in-eight-charts (20 January).

Loo, B.P.Y., Banister, D., 2016. Decoupling transport from economic growth: Extending the debate to include environmental and social externalities. J. Transp. Geogr. 57, 134-144.

Lorusso, A., Calistri, P., Petrini, A., Savini, G., Decaro, N., 2020. Novel coronavirus (SARS-CoV-2) epidemic: a veterinary perspective. Veterinaria Italiana 
Mao, L., 2011. Evaluating the combined effectiveness of influenza control strategies and human preventive behavior. PLoS ONE 6, e24706.

Mateus, A.L.P., Otete, H.E., Beck, C.R., Dolan, G.P., Nguyen-Van-Tam, J.S., 2014. Effectiveness of travel restrictions in the rapid containment of human influenza: a systematic review. Bull. World Health Organ. 92, 868-880.

McMahon, B.J., Morand, S., Gray, J.S., 2018. Ecosystem change and zoonoses in the Anthropocene. Zoonoses Public Health 65, 755-765.

McNeill, J.R., Engelke, P., 2016. The great acceleration: An environmental history of the Anthropocene since 1945. Harvard University Press, Cambridge, Massachusetts, USA.

Morand, S., 2015. Diversity and origins of human infectious diseases. In: Muehlenbein, M.P. (Ed.), Basics in human evolution. Academic Press, London, UK, pp. 405-414.

Morand, S., Figuié, M., (Eds.), 2018. Emergence of infectious diseases: Risks and issues for societies. Éditions Quæ.

Morand, S., Lajaunie, C., 2017. Biodiversity and health: linking life, ecosystems and societies. Elsevier, Kidlington, UK.

Morand, S., Owers, K., Bordes, S., 2014. Biodiversity and emerging zoonoses. In: Yamada, A., Kahn, L.H., Kaplan, B., Monath, T.P., Woodall, J., Conti, L.A. (Eds.), Confronting emerging zoonoses: The One Health paradigm. Springer, New York, New York, USA, pp. 27-41.

Morand, S., Owers, K.A., Waret-Szkuta, A., McIntyre, K.M., Baylis, M., 2013. Climate variability and outbreaks of infectious diseases in Europe. Sci. Rep. 3, 1774.

Morand, S., Walther, B.A., 2018. Individualistic values are related to an increase in the outbreaks of infectious diseases and zoonotic diseases. Sci. Rep. 8, 3866.

Muggeo, V.M.R., 2003. Estimating regression models with unknown break-points. Stat. Med. 22, 3055-3071.

Muggeo, V.M.R., 2008. segmented: an R package to fit regression models with broken-line relationships. R News 8, 20-25.

Myers, S.S., Gaffikin, L., Golden, C.D., Ostfeld, R.S., Redford, K.H., Ricketts, T.H., Turner, W.R., Osofsky, S.A., 2013. Human health impacts of ecosystem alteration. Proc. Natl. Acad. Sci. USA 110, 18753-18760.

Nakhleh, M.K., Amal, H., Jeries, R., Broza, Y.Y., Aboud, M., Gharra, A., Ivgi, H., Khatib, S., Badarneh, S., Har-Shai, L., Glass-Marmor, L., Lejbkowicz, I., Miller, A., Badarny, S., Winer, R., Finberg, J., Cohen-Kaminsky, S., Perros, F., Montani, D., Girerd, B., Garcia, G., Simonneau, G., Nakhoul, F., Baram, S., Salim, R., Hakim, M., Gruber, M., Ronen, O., Marshak, T., Doweck, I., Nativ, O., Bahouth, Z., Shi, D.Y., Zhang, W., Hua, Q.L., Pan, Y.Y., Tao, L., Liu, H., Karban, A., Koifman, E., Rainis, T., Skapars, R., Sivins, A., Ancans, G., Liepniece-Karele, I., Kikuste, I., 
Lasina, I., Tolmanis, I., Johnson, D., Millstone, S.Z., Fulton, J., Wells, J.W., Wilf, L.H., Humbert, M., Leja, M., Peled, N., Haick, H., 2017. Diagnosis and classification of 17 diseases from 1404 subjects via pattern analysis of exhaled molecules. ACS Nano 11, 112-125.

Nasreen, S., Ben Mbarek, M., Atiq-ur-Rehman, M., 2020. Long-run causal relationship between economic growth, transport energy consumption and environmental quality in Asian countries: Evidence from heterogeneous panel methods. Energy 192, 10.

Nicolaides, C., Avraam, D., Cueto-Felgueroso, L., Gonzalez, M.C., Juanes, R., 2019. Hand-hygiene mitigation strategies against global disease spreading through the air transportation network. Risk Anal. https://doi.org/10.1111/risa.13438

Oliveira, A.R.S., Piaggio, J., Cohnstaedt, L.W., McVey, D.S., Cernicchiaro, N., 2018. A quantitative risk assessment (QRA) of the risk of introduction of the Japanese encephalitis virus (JEV) in the United States via infected mosquitoes transported in aircraft and cargo ships. Prev. Vet. Med. $160,1-9$.

Oliver, H.C., 2006. In the wake of structural adjustment programs - Exploring the relationship between domestic policies and health outcomes in Argentina and Uruguay. Can. J. Public HealthRev. Can. Sante Publ. 97, 217-221.

Opsahl, T., 2009. Structure and evolution of weighted networks. PhD thesis. Queen Mary, University of London, London, UK.

Patz, J.A., Daszak, P., Tabor, G.M., Aguirre, A.A., Pearl, M., Epstein, J., Wolfe, N.D., Kilpatrick, A.M., Foufopoulos, J., Molyneux, D., Bradley, D.J., Emergence, M.o.t.W.G.o.L.U.C.a.D., 2004. Unhealthy landscapes: Policy recommendations on land use change and infectious disease emergence. Envir. Health Persp. 112, 1092-1098.

Pereira, H.M., Leadley, P.W., Proença, V., Alkemade, R., Scharlemann, J.P.W., FernandezManjarrés, J.F., Araújo, M.B., Balvanera, P., Biggs, R., Cheung, W.W.L., Chini, L., Cooper, H.D., Gilman, E.L., Guénette, S., Hurtt, G.C., Huntington, H.P., Mace, G.M., Oberdorff, T., Revenga, C., Rodrigues, P., Scholes, R.J., Sumaila, U.R., Walpole, M., 2010. Scenarios for global biodiversity in the 21 st century. Science 330, 1496-1501.

Permanyer, I., Scholl, N., 2019. Global trends in lifespan inequality: 1950-2015. PLoS ONE 14, $\mathrm{e} 0215742$.

Plowright, R.K., Sokolow, S.H., Gorman, M.E., Daszak, P., Foley, J.E., 2008. Causal inference in disease ecology: investigating ecological drivers of disease emergence. Front. Ecol. Environ. 6, 420-429.

Poisot, T., Nunn, C., Morand, S., 2014. Ongoing worldwide homogenization of human pathogens. bioRxiv. https://doi.org/10.1101/009977 
Pongsiri, M.J., Roman, J., Ezenwa, V.O., Goldberg, T.L., Koren, H.S., Newbold, S.C., Ostfeld, R.S., Pattanayak, S.K., Salkeld, D.J., 2009. Biodiversity loss affects global disease ecology. BioScience 59, 945-954.

Purwanto, J., de Ceuster, G., Vanherle, K., 2017. Mobility, Vehicle fleet, Energy use and Emissions forecast Tool (MOVEET). Transp. Res. Proc. 25, 3421-3434.

R Development Core Team, 2019. The R Project for Statistical Computing. R Foundation for Statistical Computing. https://www.r-project.org/

Ripple, W.J., Wolf, C., Newsome, T.M., Barnard, P., Moomaw, W.R., 2020. World scientists' warning of a climate emergency. BioScience 70, 8-12.

Rohr, J.R., Barrett, C.B., Civitello, D.J., Craft, M.E., Delius, B., DeLeo, G.A., Hudson, P.J., Jouanard, N., Nguyen, K.H., Ostfeld, R.S., Remais, J.V., Riveau, G., Sokolow, S.H., Tilman, D., 2019. Emerging human infectious diseases and the links to global food production. Nat. Sustain. 2, 445-456.

Rosen, G.E., Smith, K.F., 2010. Summarizing the evidence on the international trade in illegal wildlife. EcoHealth 7, 24-32.

Saidi, S., Shahbaz, M., Akhtar, P., 2018. The long-run relationships between transport energy consumption, transport infrastructure, and economic growth in MENA countries. Transp. Res. Pt. A 111, 78-95.

Sandberg, M., Klockars, K., Wilen, K., 2019. Green growth or degrowth? Assessing the normative justifications for environmental sustainability and economic growth through critical social theory. J. Clean Prod. 206, 133-141.

Sandifer, P.A., Sutton-Grier, A.E., Ward, B.P., 2015. Exploring connections among nature, biodiversity, ecosystem services, and human health and well-being: Opportunities to enhance health and biodiversity conservation. Ecosyst. Serv. 12, 1-15.

Sardain, A., Sardain, E., Leung, B., 2019. Global forecasts of shipping traffic and biological invasions to 2050. Nat. Sustain. 2, 274-282.

Schill, C., Anderies, J.M., Lindahl, T., Folke, C., Polasky, S., Cardenas, J.C., Crepin, A.S., Janssen, M.A., Norberg, J., Schluter, M., 2019. A more dynamic understanding of human behaviour for the Anthropocene. Nat. Sustain. 2, 1075-1082.

Schmid, B., 2019. Degrowth and postcapitalism: Transformative geographies beyond accumulation and growth. Geogr. Compass 13, 15.

Schneider, F., Kallis, G., Martinez-Alier, J., 2010. Crisis or opportunity? Economic degrowth for social equity and ecological sustainability. Introduction to this special issue. J. Clean Prod. 18, 511-518. 
Schneider, J.L., 2012. Sold into extinction: The global trade in endangered species. ABC-CLIO, Santa Barbara, California, USA.

Sevilla, N.L., 2018. Germs on a plane: The transmission and risks of airplane-borne diseases. Transp. Res. Record 2672, 93-102.

Simms, A., 2016. Conventional thinking will not solve the climate crisis. The Guardian. https://www.theguardian.com/environment/2016/oct/19/conventional-thinking-will-not-solvethe-climate-crisis (19 October).

Smith, K.F., Goldberg, M., Rosenthal, S., Carlson, L., Chen, J., Chen, C., Ramachandran, S., 2014. Global rise in human infectious disease outbreaks. J. Roy. Soc. Interface 11, 20140950.

Smith, K.F., Guégan, J.-F., 2010. Changing geographic distributions of human pathogens. Annu. Rev. Ecol. Evol. Syst. 41, 231-250.

Smith, K.F., Sax, D.F., Gaines, S.D., Guernier, V., Guégan, J.-F., 2007. Globalization of human infectious disease. Ecology 88, 1903-1910.

Steffen, W., Broadgate, W., Deutsch, L., Gaffney, O., Ludwig, C., 2015a. The trajectory of the Anthropocene: the great acceleration. Anthropocene Rev. 2, 81-98.

Steffen, W., Richardson, K., Rockström, J., Cornell, S.E., Fetzer, I., Bennett, E.M., Biggs, R., Carpenter, S.R., De Vries, W., De Wit, C.A., 2015b. Planetary boundaries: Guiding human development on a changing planet. Science 347, 736.

Steffen, W., Rockstrom, J., Richardson, K., Lenton, T.M., Folke, C., Liverman, D., Summerhayes, C.P., Barnosky, A.D., Cornell, S.E., Crucifix, M., Donges, J.F., Fetzer, I., Lade, S.J., Scheffer, M., Winkelmann, R., Schellnhuber, H.J., 2018. Trajectories of the Earth System in the Anthropocene. Proc. Natl. Acad. Sci. USA 115, 8252-8259.

Stopford, M., 2009. Maritime economics, third edition. Routledge.

Tao, D.Y., McGill, B., Hamerly, T., Kobayashi, T., Khare, P., Dziedzic, A., Leski, T., Holtz, A., Shull, B., Jedlicka, A.E., Walzer, A., Slowey, P.D., Slowey, C.C., Nsango, S.E., Stenger, D.A., Chaponda, M., Mulenga, M., Jacobsen, K.H., Sullivan, D.J., Ryan, S.J., Ansumana, R., Moss, W.J., Morlais, I., Dinglasan, R.R., 2019. A saliva-based rapid test to quantify the infectious subclinical malaria parasite reservoir. Sci. Transl. Med. 11, 13.

Tatem, A.J., Hay, S.I., Rogers, D.J., 2006. Global traffic and disease vector dispersal. Proc. Natl. Acad. Sci. USA 103, 6242-6247.

Thébault, E., 2013. Identifying compartments in presence-absence matrices and bipartite networks: insights into modularity measures. J. Biogeogr. 40, 759-768.

Tildesley, M.J., Brand, S., Pollock, E.B., Bradbury, N.V., Werkman, M., Keeling, M.J., 2019. The role of movement restrictions in limiting the economic impact of livestock infections. Nat. Sustain. 2, 834-840. 
Tognotti, E., 2013. Lessons from the history of quarantine, from plague to influenza A. Emerg. Infect. Dis 19, 254-259.

Tournadre, J., 2014. Anthropogenic pressure on the open ocean: The growth of ship traffic revealed by altimeter data analysis. Geophys. Res. Lett. 41, 7924-7932.

Tylianakis, J.M., Tscharntke, T., Lewis, O.T., 2007. Habitat modification alters the structure of tropical host-parasitoid food webs. Nature 445, 202-205.

UN, 2017. International Migration Report 2017 (ST/ESA/SER.A/403). United Nations, Department of Economic and Social Affairs, Population Division, New York, New York, USA.

UNCTAD, 2005. UNCTAD handbook of statistics 2005. United Nations Conference on Trade and Development, New York, New York, USA.

UNCTAD, 2019a. Review of Maritime Transport 2019. United Nations Conference on Trade and Development, New York, New York, USA. https://unctad.org/en/PublicationsLibrary/rmt2019_en.pdf

UNCTAD, 2019b. UNCTAD handbook of statistics 2019. United Nations Conference on Trade and Development, New York, New York, USA.

UNEP, 2016. Global Environmental Outlook GEO-6. United Nations Environment Programme, Nairobi, Kenya. https://www.unenvironment.org/resources/global-environment-outlook-6 Unmüßig, B., 2015. Radical goals for sustainable development. Heinrich Böll Stiftung. http://www.be.boell.org/en/2015/01/12/radical-goals-sustainable-development (12 January). UNWTO, 2017. UNWTO tourism highlights. 2017 edition. World Tourism Organization (UNWTO), Madrid, Spain.

UNWTO, 2019. UNWTO tourism highlights. 2019 edition. World Tourism Organization (UNWTO), Madrid, Spain.

UNWTO, 2020. Tourism towards 2030. Global overview. World Tourism Organization (UNWTO), Madrid, Spain. https://www.e-unwto.org/doi/pdf/10.18111/9789284414024

Waage, J., Banerji, R., Campbell, O., Chirwa, E., Collender, G., Dieltiens, V., Dorward, A., Godfrey-Faussett, P., Hanvoravongchai, P., Kingdon, G., Little, A., Mills, A., Mulholland, K., Mwinga, A., North, A., Patcharanarumol, W., Poulton, C., Tangcharoensathien, V., Unterhalter, E., 2010. The Millennium Development Goals: a cross-sectoral analysis and principles for goal setting after 2015. Lancet 376, 991-1023.

Walther, B., 2019. The radical rebuilding of societies. Taipei Times. http://www.taipeitimes.com/News/editorials/archives/2019/01/17/2003708062 (17 January). Walther, B.A., Boëte, C., Binot, A., By, Y., Cappelle, J., Carrique-Mas, J.J., Chou, M., Furey, N., Kim, S., Lajaunie, C., Lek, S., Méral, P., Neang, M., Tan, B.-H., Walton, C., Morand, S., 2016. 
Biodiversity and health: Lessons and recommendations from an interdisciplinary conference to advise Southeast Asian research, society and policy. Infect. Genetics Evol. 40, 29-46.

Walther, B.A., Ewald, P.W., 2004. Pathogen survival in the external environment and the evolution of virulence. Biol. Rev. 79, 849-869.

WATF, 2019. Annual world airport traffic forecasts 2019-2040. Airports Council International, Montreal, Canada.

Weiss, M., Cattaneo, C., 2017. Degrowth - taking stock and reviewing an emerging academic paradigm. Ecol. Econ. 137, 220-230.

Wells, K., Morand, S., Wardeh, M., Baylis, M., 2020. Distinct spread of DNA and RNA viruses among mammals amid prominent role of domestic species. Glob. Ecol. Biogeogr. 12.

Wilcox, B.A., Gubler, D.J., 2005. Disease ecology and the global emergence of zoonotic pathogens. Environ. Health Prev. Med. 10, 263-272.

Wilson, M.E., 1995. Travel and the emergence of infectious diseases. Emerg. Infect. Dis. 1, 39-46.

Wilson, M.E., 1997. Population movements and emerging diseases. J. Travel Med. 4, 183-186.

Wood, C.L., Lafferty, K.D., DeLeo, G., Young, H.S., Hudson, P.J., Kuris, A.M., 2014. Does biodiversity protect humans against infectious disease? Ecology 95, 817-832.

World Bank, 2020a. Air transport, freight (million ton-km). https://data.worldbank.org/indicator/IS.AIR.GOOD.MT.K1

World Bank, 2020b. Air transport, passengers carried. https://data.worldbank.org/indicator/IS.AIR.PSGR

World Ocean Review, 2010. Maritime highways of global trade. In: Living with the oceans. A report on the state of the world's oceans. maribus gGmbH, Hamburg, Germany, pp. 162-175.

Yercan, F., Yildiz, T., 2012. International maritime trade and logistics. In: Song, D.-W., Panayides, P.M. (Eds.), Maritime logistics: A complete guide to effective shipping and port management. pp. $23-44$.

Zainabadi, K., Dhayabaran, V., Moideen, K., Krishnaswamy, P., 2019. An efficient and costeffective method for purification of small sized DNAs and RNAs from human urine. PLoS ONE 14, $\mathrm{e} 0210813$.

Zheng, Y., Qian, J., (Eds.), 2019. Development and poverty reduction: a global comparative perspective. Routledge, Abingdon-on-Thames, UK.

Zhou, P., Yang, X.-L., Wang, X.-G., Hu, B., Zhang, L., Zhang, W., Si, H.-R., Zhu, Y., Li, B., Huang, C.-L., Chen, H.-D., Chen, J., Luo, Y., Guo, H., Jiang, R.-D., Liu, M.-Q., Chen, Y., Shen, X.-R., Wang, X., Zheng, X.-S., Zhao, K., Chen, Q.-J., Deng, F., Liu, L.-L., Yan, B., Zhan, F.-X., Wang, Y.-Y., Xiao, G.-F., Shi, Z.-L., 2020. A pneumonia outbreak associated with a new coronavirus of probable bat origin. Nature 579, 270-273. 

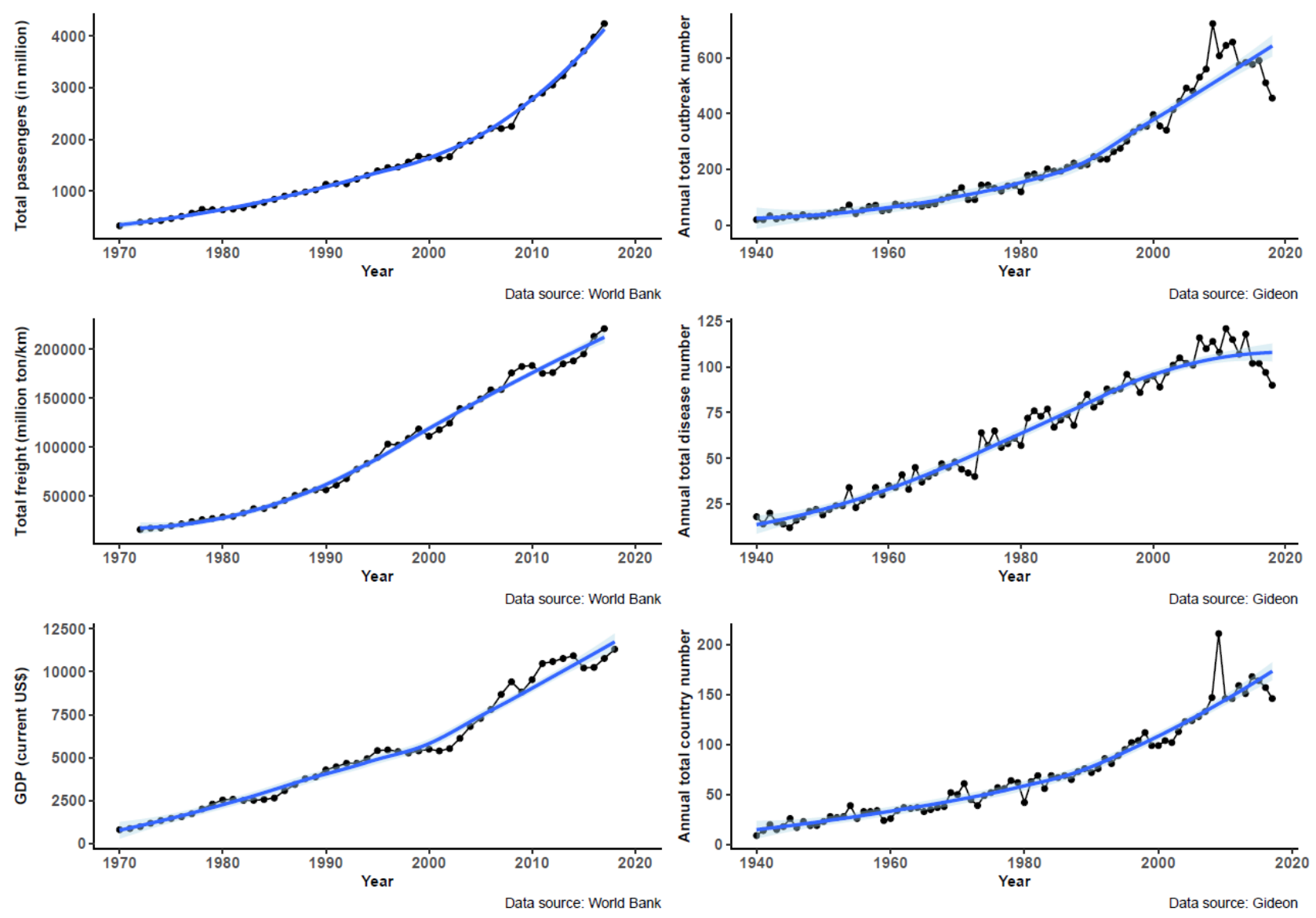

Fig. 1. The increase of air travel, GDP, and disease outbreaks since the 1940s. Resulting graphs from plotting the total global number of air passengers (A), total global air freight (B), and global GDP from 1970 to 2017; and the annual total outbreak number (A), the annual total disease number (B) and the annual total country number (C) from 1940 to 2018. Fitted smooth regressions (in blue) with confidence intervals (in light blue) are shown. 
bioRxiv preprint doi: https://doi.org/10.1101/2020.04.20.049866; this version posted April 20, 2020. The copyright holder for this preprint (which was not certified by peer review) is the author/funder, who has granted bioRxiv a license to display the preprint in perpetuity. It is made available under aCC-BY-NC-ND 4.0 International license.

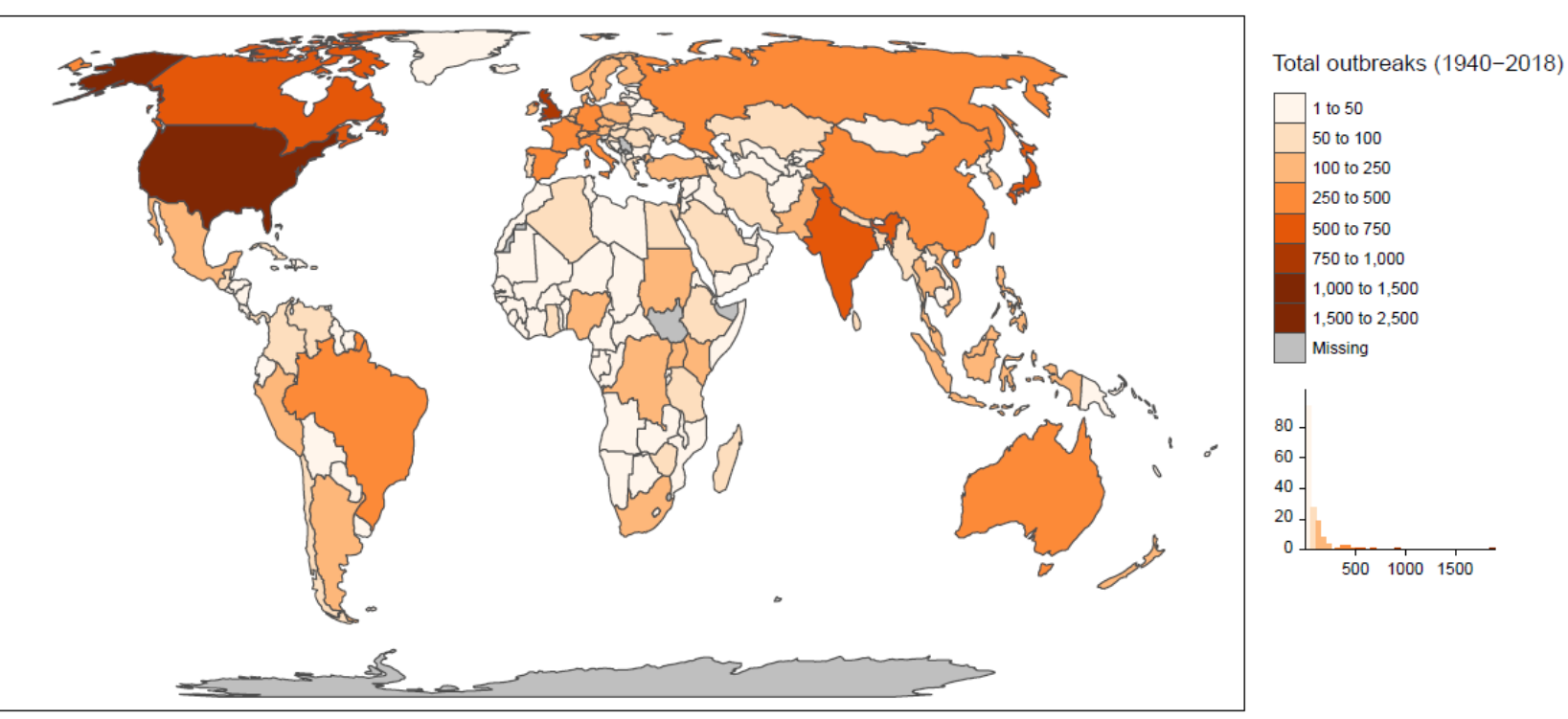

Fig. 2. | World map of total disease outbreaks from 1940 to 2018. The frequency histogram is also included. 
bioRxiv preprint doi: https://doi.org/10.1101/2020.04 20 049866; this version posted April 20, 2020. The copyright holder for this preprint (which was not certified by peer review) is the author/funder, who has granted bioRxiv a license to display the preprint in perpetuity. It is made available under aCC-BY-NC-ND 4.0 International license.

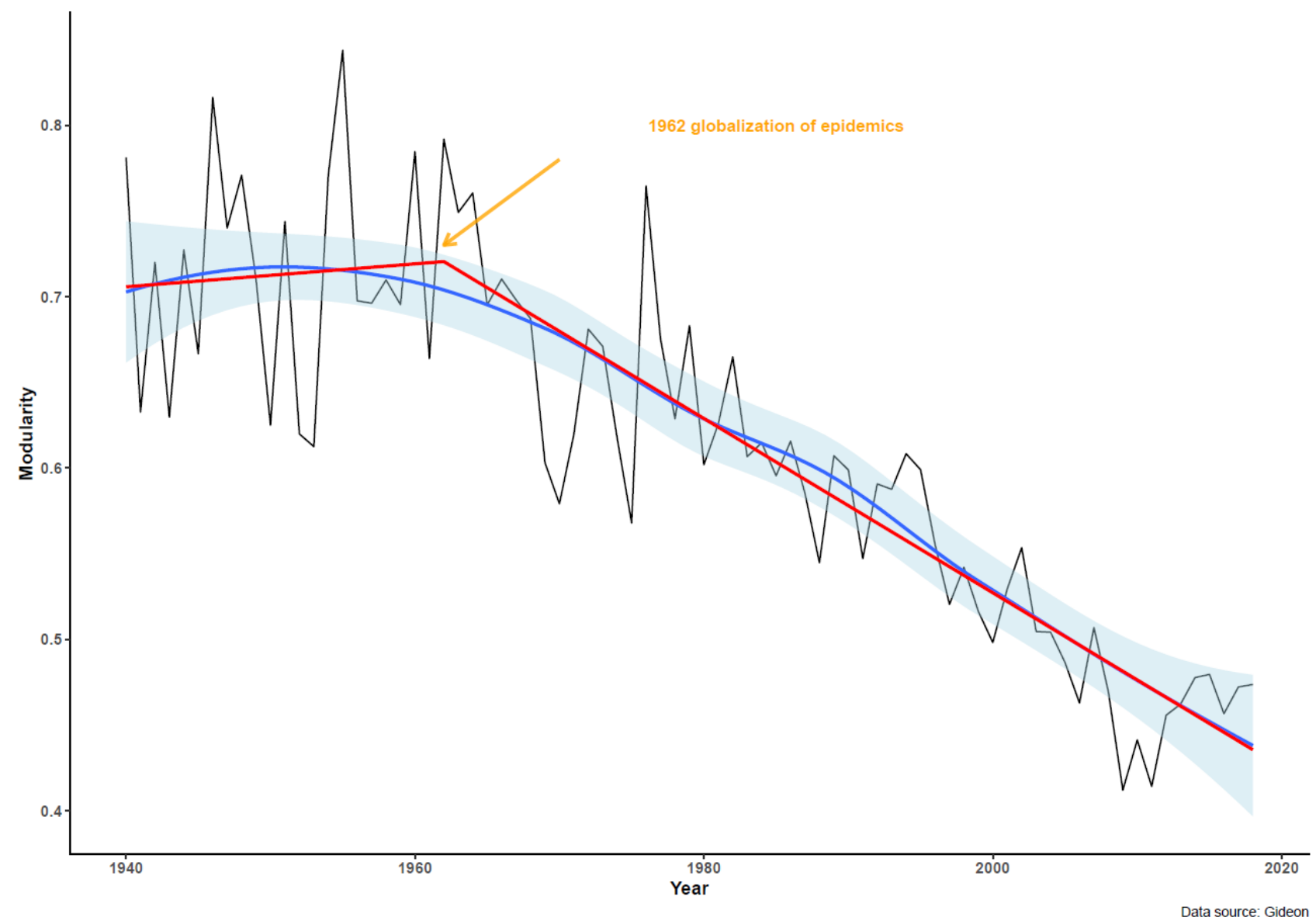

Fig. 3. The decrease in the modularity of outbreaks since the 1940s. The graph from plotting the annual modularity measure from 1940 to 2018 . We also fitted a smooth regression (in blue) with confidence intervals (in light blue). The two red lines display the results of the discontinuity analysis which split the trend into two parts with an estimated breakpoint in 1962 (see details in Results). 

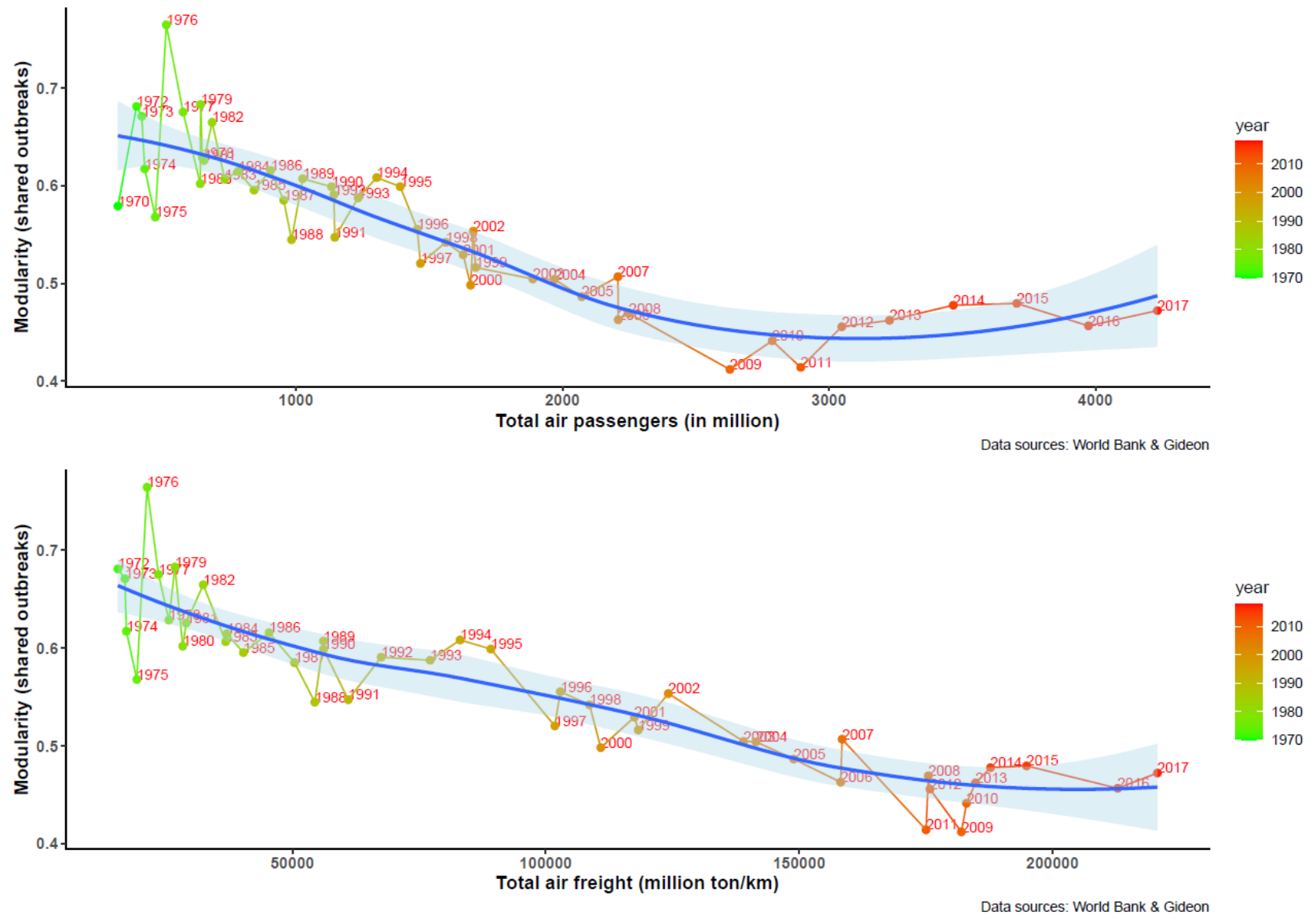

Fig. 4. Correlation between annual modularity and in air travel and transport since the

1970s. Resulting graphs from plotting the (A) annual global number of air passengers and (B) annual global total of air freight (cf. Fig. 1) against the annual modularity measure (cf. Fig. 3) from 1970 to 2017. Fitted smooth regressions (in blue) with confidence intervals (in light blue) are shown. 
bioRxiv preprint doi: $h$ ttps://doi.org/10.1101/2020.04 20.049866; this version posted April 20, 2020. The copyright holder for this preprint (which was not certified by peer review) is the author/funder, who has granted bioRxiv a license to display the preprint in perpetuity. It is made available under aCC-BY-NC-ND 4.0 International license.

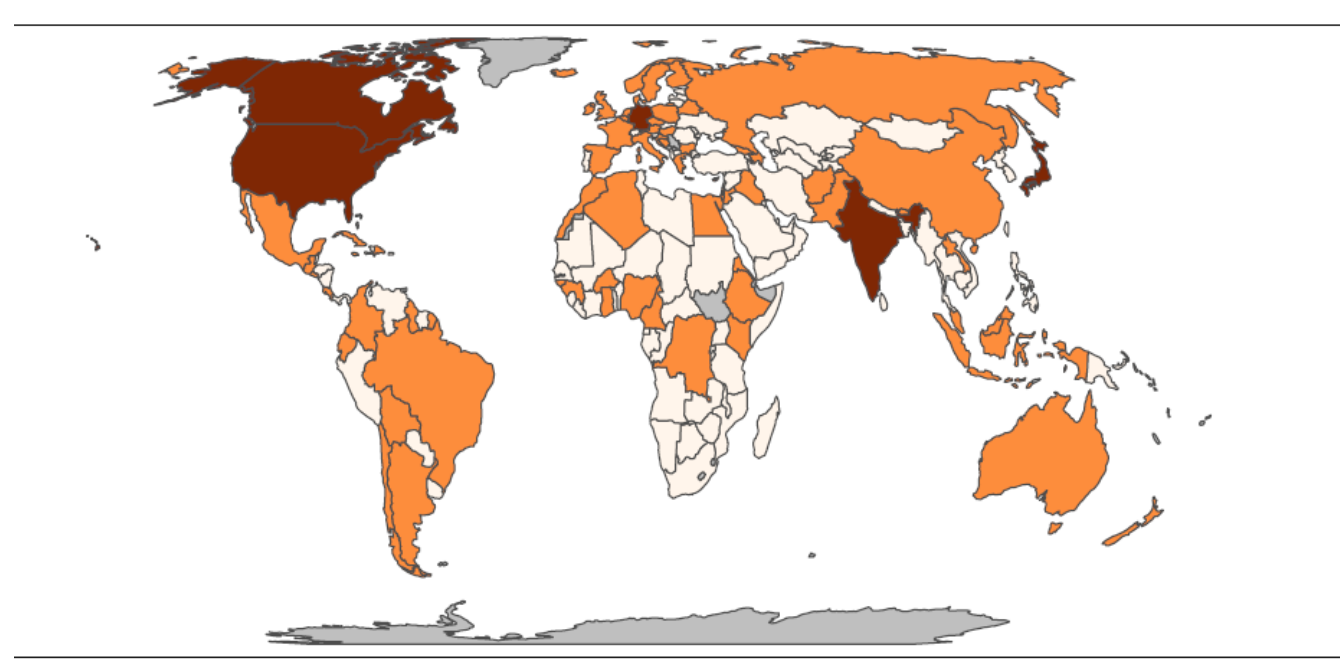

Mean centrality $(1940-2018)$
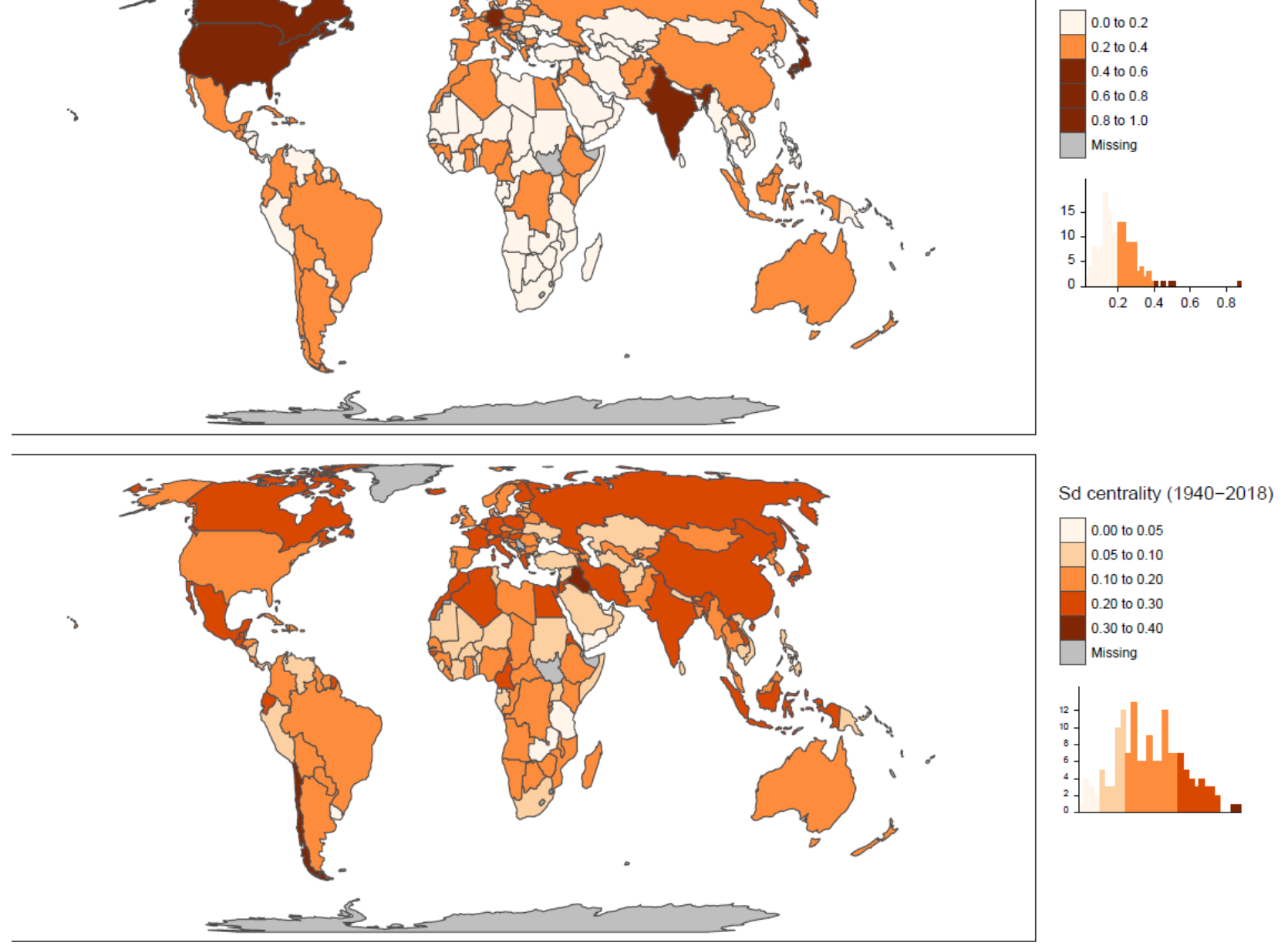

Sd centrality (1940-2018)

Fig. 5. | World map of centrality measures from 1940 to 2018. (A) Mean centrality values of shared disease outbreaks and (B) their variability (using the standard deviation). The frequency histograms are also included. 
bioRxiv preprint doi: https://doi.org/10.1101/2020.04.20.049866; this version posted April 20, 2020. The copyright holder for this preprint (which was not certified by peer review) is the author/funder, who has granted bioRxiv a license to display the preprint in perpetuity. It is made available under aCC-BY-NC-ND 4.0 International license.

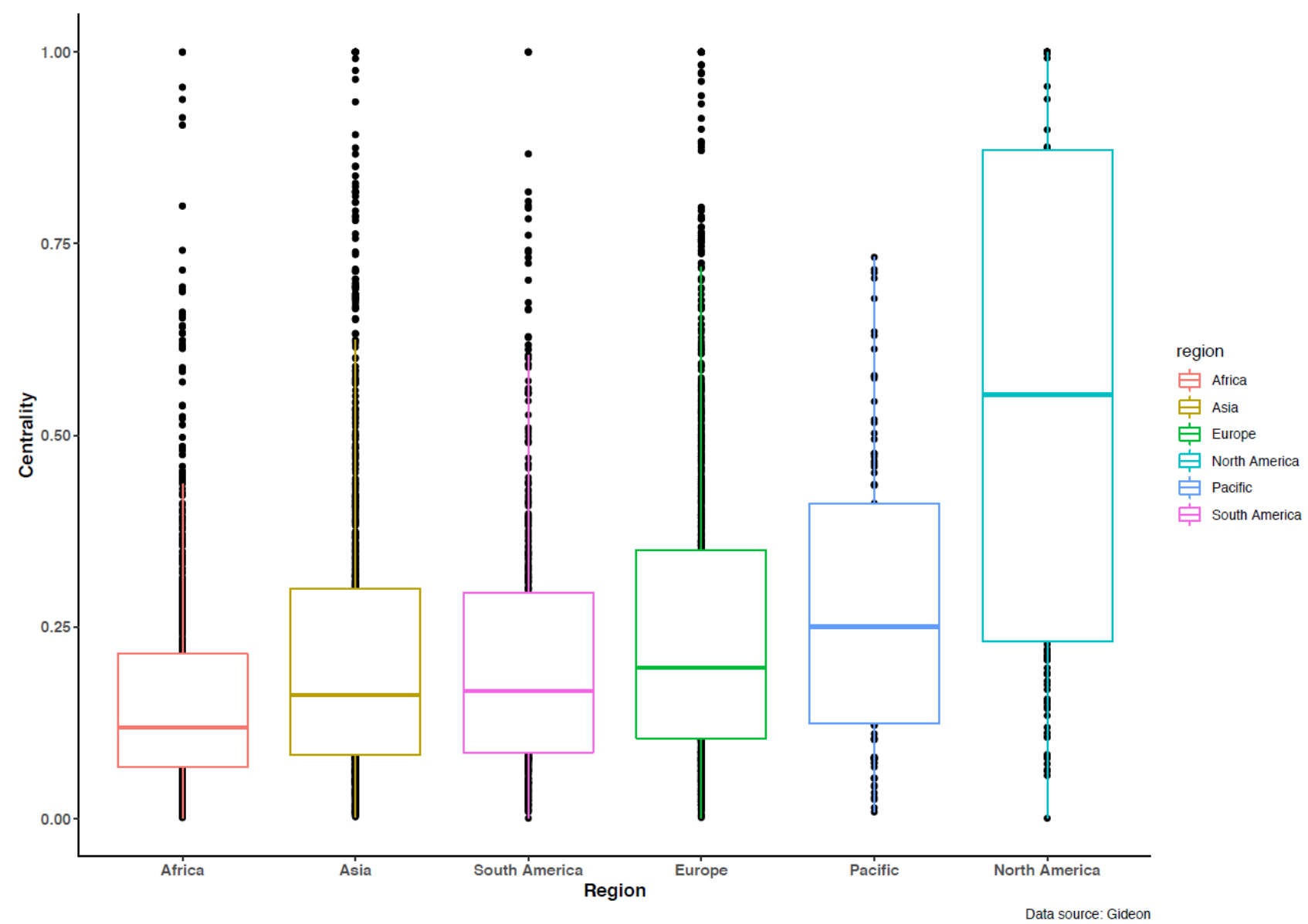

Fig. 6. | Box plots of centrality measures for six regions. Box plots of all annual centrality values (1940-2018) for all countries in Africa ( $n=45$ countries), Asia ( $n=48$ countries), South America ( $n$ $=25$ countries), Europe $(n=40$ countries), Pacific $(n=3$ countries $)$, and North America $(n=3$ countries). 
Table 1 | Evidence for increase in global measures of mobility during the Anthropocene.

\begin{tabular}{|c|c|c|c|}
\hline Time period & Variable & Increase (total amount and percentage $e^{\$}$ ) & References \\
\hline $1950-2010$ & Traffic vehicles for transportation & $<200$ to $>1200$ million motor vehicles $(>600 \%)$ & (Steffen et al., 2015a) \\
\hline $1950-2010$ & International tourism & $<100$ to $>900$ million arrivals $(>900 \%)$ & (Steffen et al., 2015a) \\
\hline $1950-2016$ & International tourism & 25 to 1400 million arrivals (5600\%) & (UNWTO, 2017; UNWTO, 2019) \\
\hline $1950-2008$ & Seaborne trade & 0.5 to 11.0 billion MT of seaborne cargo $(2200 \%)$ & $\begin{array}{l}\text { (Stopford, 2009; Yercan and Yildiz, 2012; } \\
\text { UNCTAD, 2019b) }\end{array}$ \\
\hline $1950-2005$ & Global merchant fleet & 84.6 to 652.5 million MT (771\%) & (Stopford, 2009) \\
\hline $1950 s-2000 s$ & World trade & $-(>300 \%)$ & (World Ocean Review, 2010) \\
\hline $1950 s-2000 s$ & $\begin{array}{l}\text { World trade of goods destined for } \\
\text { the processing industry }\end{array}$ & $-(>400 \%)$ & (World Ocean Review, 2010) \\
\hline $1970-2017$ & Air travel & 0.33 to 4.00 billion passengers $(1212 \%)$ & Figure 1A (World Bank, 2020a) \\
\hline $1970-2017$ & Air freight & 15660 to 220707 million MT/km (1409\%) & Figure 1B (World Bank, 2020b) \\
\hline $1980-2004$ & $\begin{array}{l}\text { Global value of trade (exports and } \\
\text { imports) }\end{array}$ & 2033075 to 8975589 million dollars (441\%) & (UNCTAD, 2005) \\
\hline $1980-2009$ & Global merchant ship fleet & 683 to 1192 capacity in million MT (174\%) & (World Ocean Review, 2010) \\
\hline $1980-2018$ & Containers & 34.9 to 680.8 million TEU containers $(1951 \%)$ & $\begin{array}{l}\text { Institute of Shipping Economics and Logistics } \\
\text { (in litt., 2020) }\end{array}$ \\
\hline $1980-2018$ & International maritime trade & 2605 to 11005 million MT loaded (422\%) & (UNCTAD, 2019a) \\
\hline $1990-2017$ & International migrants & 152.5 to 257.7 million $(169 \%)$ & (UN, 2017) \\
\hline $1992-2018$ & Total ship number & 28666 to 98755 ships $(344 \%)$ & $\begin{array}{l}\text { (Tournadre, 2014); Jean Tournadre (in litt., } \\
\text { 2020) }\end{array}$ \\
\hline
\end{tabular}


${ }^{\$}$ Calculated as percentage increase by dividing the later estimate by the earlier estimate. The numbers and percentages given in this Table are approximations whenever numbers are given with $\mathrm{a} \sim,<$ or $>$ sign because these numbers were taken from graphs in Steffen et al. (2015a) and ISL (2017). Abbreviations: DWT

$=$ deadweight tonnage is a measure of how much weight a ship can carry; MT = metric ton; TEU = twenty-foot equivalent unit, a standard size for $6.1 \mathrm{~m}$ long containers. 